\title{
Using DNA microsatellites for maternity testing in honeybees (Apis mellifera L.)
}

\author{
Peter Neumann ${ }^{\mathrm{a}, \mathrm{b}}$, Robin F.A. Moritz ${ }^{\mathrm{a} *}$, Dietrich Mautz ${ }^{\mathrm{c}}$ \\ a Institut für Zoologie, Molekulare Ökologie, Martin-Luther-Universität Halle-Wittenberg, \\ Kröllwitzerstr. 44, 06099 Halle/Saale, Germany \\ ${ }^{b}$ Department of Zoology and Entomology, Rhodes University, Grahamstown 6140, South Africa \\ c Bayerische Landesanstalt für Bienenzucht, Burgbergstr. 70, 91054 Erlangen, Germany
}

(Received 12 October 1998; revised 7 June 1999; accepted 18 June 1999)

\begin{abstract}
Performance testing in honeybees relies on comparing colony traits of commercial interest in a 1- or 2-year test period. Groups of sister colonies are tested to determine breeding values and the procedure is gravely distorted if unrelated queens are included in the sister groups. Maternity was verified in nine sister queen groups from a routine performance test. Individual workers $(n=40)$ were taken from 36 queenright colonies and genotyped using four DNA microsatellites. Queen genotypes were derived from the worker offspring. The consistency of maternity of the sister queen groups was evaluated using the number of alleles per locus and the putative mother queen genotypes. One group unambiguously included non-sister queens. In our tested population, the probability of not detecting unrelated queens ranged from $<0.001$ up to 0.005 depending on the putative mother queen genotype. In light of the high costs and labour of testing colony traits, we recommend including maternity testing into the routine procedure of honeybee performance testing. (C) Inra/DIB/AGIB/Elsevier, Paris
\end{abstract}

Apis mellifera / DNA microsatellite / performance testing / queen rearing / maternity testing / sister queen

\section{INTRODUCTION}

Performance testing and selective honeybee breeding is based on comparing groups of colonies with sister queens. The pedigree information of the queens is essential for selection and evaluation of breeding values at the level of the colony phenotype. The groups of colonies with sister queens are usually evaluated at performance

\footnotetext{
* Correspondence and reprints

E-mail: r.moritz@zoologie.uni-halle.de
} 
apiaries over a period of 2 years. For example in the testing procedure of the Bavarian Institute for Bee Breeding, bee breeders provide groups of ten sister queens which are introduced into standardized test colonies. Various colony traits such as levels of infestation with parasites or honey yields are evaluated over the testing period. However, the evaluation of the performance data is meaningless if 'sister queen' groups are not composed of sister queens. Errors may be due to mistakes in queen-rearing management on the part of the bee breeder or during the introduction of the queens.

Advances in honeybee DNA microsatellite technology $[3,4]$ allow one to confirm the maternity of sister queen groups in honeybee performance testing. Since the queens' genotypes can be derived from their worker offspring, the breeding lines of the sister groups can be verified without sacrificing the queens. Only the two maternal alleles need to be confirmed for each locus. Therefore, only small samples are needed which can be taken and analysed easily at low cost. Thus, the integrity of breeding lines and performance groups can be evaluated precisely without interfering with colony performance and routine operating conditions at the apiary.

In this study we use DNA microsatellites to: 1) genotype worker offspring of the tested queens, 2) derive the queen genotypes from her offspring, and 3) identify test groups which are composed of non-sister queens.

\section{MATERIALS AND METHODS}

\subsection{Sampling and genotyping}

Thirty-six queenright honeybee colonies of nine test groups were performance tested at the apiary Schwarzenau (Germany) in June 1995 [1]. For each colony, DNA was phenol extracted from at least 40 individual workers [8]. Individuals were genotyped using four DNA microsatellite loci (A43, A76, A107, B 124) standard protocols of Estoup et al. [3, 4]. The genotypes of the queens and of the drones were determined from the genotypes of the worker offspring. The queen was assumed to be homozygous when an allele was present in every worker of the colony. The queen was considered to be heterozygous when every worker carried one of two alleles.

We used two different approaches to test the integrity of the sister queen groups. Since honeybee queens mate with many males $[4,7]$, each tested queen might potentially belong to another patriline of the maternal colony. Therefore, the maximum number of paternal alleles in a group of honeybee sister queens must be assumed to be equal to the number of queens. The maximum number of maternal alleles is two in case of heterozygosity of the mother queen. Hence, the pedigree information of the tested queen groups can be investigated by simply counting the number of alleles at each microsatellite locus and taking into account homozygous genotypes. Non-sister queens are unequivocally included in a group of $n$ individuals if:

1) more than two different homozygous genotypes can be found;

2) the number of alleles exceeds $n$ if two different homozygous genotypes are present in the group;

3) the number of alleles exceeds $n+1$ if one homozygous genotype is present in the group;

4) the number of alleles exceeds $n+2$ if no homozygous genotype is present in the group.

However, some groups may be composed of queen genotypes with less than $n, n+1$ or $n+2$ alleles and nevertheless include non-sister queens owing to a potential low discriminatory power of the microsatellites employed for the analysis. Therefore, it is also important to evaluate the individual genotypes of all tested queens. Since daughters inherit only one out of two maternal alleles at each locus from their mother, all queens within the tested groups must share at least one (in the case of homozygosity of the mother queen) or one out of two (in the case of heterozygosity of the mother queen) alleles at each locus. These shared alleles among the genotypes of the tested queens represent the putative mother queen genotype of each tested group. Each homozygous genotype determines one putative maternal allele. If queens in a tested group did not share these putative mother queen alleles at each locus, the group unequivocally included non-sister queens. If a group were composed of matching queen genotypes, it was assumed to consist of sister queens thus allowing for second order errors. 


\subsection{Error analysis}

As in any test system, first and second order errors may occur. First order errors (identification of an unrelated queen although it was a sister) may stem from mutational events. Second order errors (non-detection of an unrelated queen) result from unrelated queens sharing at least one of the maternal alleles of the sister queens. Second order errors depend on the discrimination power of the analysis which is determined by the maternal allele frequencies of each of the tested microsatellite loci. The mother of the sister queen group has two alleles $m_{1}$ and $m_{2}$ at a given marker locus. Since we can estimate the maternal allele frequencies, $f_{m 1}$ and $f_{m 2}$, in the population from the worker sample, we can calculate the probability of sampling the two alleles in unrelated queens. This is the combined probability that the unrelated queens carry at least one allele of the mother queen. Given the population is in Hardy-Weinberg equilibrium, the probability of finding an identical allele in an unrelated queen, here termed the non-detection error, $e_{l}$, for any given locus, $l$, is

$$
\begin{gathered}
e_{l}=\left(1-f_{m 1}\right) f_{m 1}+\left(1-f_{m 2}\right) f_{m 2}+f_{m 1}^{2}+f_{m 2^{2}} \\
=\mathrm{f}_{\mathrm{m} 1}+\mathrm{f}_{\mathrm{m} 2}
\end{gathered}
$$

where $e_{l}=$ non-detection at locus $l, f_{m 1}=$ frequency of first maternal allele, and $f_{m 2}=$ frequency of second maternal allele.

If we increase the number of non-linked marker loci the total non-detection error $E$ becomes smaller and is the product of all $e_{l}$ :

$$
\mathbf{R}=\prod_{l=1}^{n} e_{l}
$$

where $E=$ total non-detection error, $e_{l}=$ nondetection at locus $l$, and $n=$ number of loci.

\section{RESULTS}

A total number of 1408 workers was genotyped and assigned to patrilines. The derived queen genotypes of the tested breeding lines are shown in table I. One of the tested breeding line groups shows more than $n+2$ queen alleles at two loci (A76 and A 107, table II) and was identified as consisting of unrelated queens. The allele frequencies of the tested honeybee population are derived from the allele frequencies of the sexual reproductives in the population (table $I I I$ ). The non-detection error $E$ of unrelated queens ranged from $<0.001$ to 0.005 for our tested sister queen groups (table $I V$ ), depending on the putative genotype of the mother queen (figure 1).

\section{DISCUSSION}

Our results clearly show that DNA microsatellite analyses are feasible to reliably detect unrelated queens. One of the tested groups included non-sister queens. This shows that mistakes in queen-rearing management have occurred either during grafting or before shipping. Moreover, bee breeders may be tempted to compensate for queen losses with unrelated queens to achieve the complete test group of ten queens. We feel that one can safely exclude mutational events as a possible explanation for non-matching genotypes because muta-
Figure 1. The nondetection error of unrelated queens for the tested breeding lines as a function of the number of DNA microsatellite loci used. Breeding line $B$ is not shown because the group was identified as consisting of non-sister queens. With four loci $E$ is $0.005 \%$ smaller for all other tested groups.

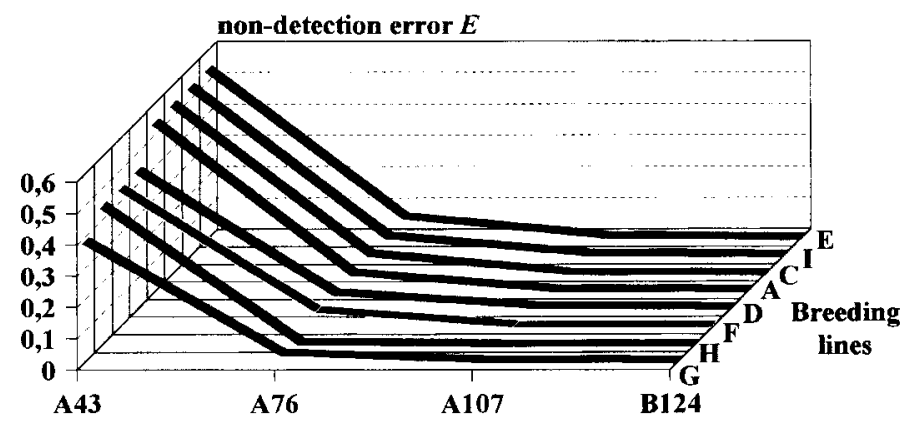

Loci included 
Table I. Putative genotypes of the queens derived from offspring workers (four microsatellite loci, length in base pairs, putative mother queen alleles are in bold, non-matching queen genotypes are framed).

\begin{tabular}{|c|c|c|c|c|c|c|c|c|c|c|c|}
\hline \multirow{2}{*}{$\begin{array}{l}\text { Sister } \\
\text { group }\end{array}$} & \multicolumn{5}{|c|}{ Locus } & \multirow{2}{*}{$\begin{array}{l}\text { Sister } \\
\text { group }\end{array}$} & \multicolumn{5}{|c|}{ Locus } \\
\hline & Queens & A76 & A 107 & B 124 & $\mathrm{~A} 43$ & & Queens & A 76 & A 107 & B 124 & A43 \\
\hline \multirow{8}{*}{ A } & 1 & 265 & 163 & 214 & 127 & $\mathrm{~F}$ & 1 & 251 & 171 & 214 & 127 \\
\hline & & 287 & 165 & 216 & 140 & & & 261 & 176 & 214 & 140 \\
\hline & 2 & 287 & 159 & 214 & 127 & & 2 & 261 & 165 & 218 & 140 \\
\hline & & 313 & 176 & 216 & 140 & & & 271 & 177 & 222 & 140 \\
\hline & 3 & 287 & 165 & 214 & 127 & & 3 & 269 & 165 & 214 & 127 \\
\hline & & 343 & 168 & 214 & 140 & & & 313 & 167 & 214 & 140 \\
\hline & 4 & 271 & 165 & 214 & 127 & & 4 & 287 & 159 & 214 & 127 \\
\hline & & 313 & 167 & 214 & 140 & & & 313 & 176 & 216 & 140 \\
\hline \multirow[t]{8}{*}{ B } & 1 & 251 & 162 & 214 & 127 & G & 1 & 251 & 158 & 214 & 127 \\
\hline & & 267 & 174 & 214 & 140 & & & 287 & 163 & 214 & 140 \\
\hline & 2 & 251 & 167 & 214 & 140 & & 2 & 251 & 158 & 214 & 127 \\
\hline & & 295 & 17.1 & 216 & 140 & & & 313 & 164 & 218 & 127 \\
\hline & 3 & 305 & 166 & 214 & 140 & & 3 & 251 & 160 & 214 & 127 \\
\hline & & 313 & 176 & 216 & 142 & & & 305 & 160 & 222 & 140 \\
\hline & 4 & 239 & 160 & 214 & 127 & & 4 & 251 & 160 & 214 & 127 \\
\hline & & 283 & 177 & 216 & 140 & & & 265 & 168 & 222 & 140 \\
\hline \multirow[t]{8}{*}{$\mathrm{C}$} & 1 & 257 & 165 & 214 & 127 & $\mathrm{H}$ & 1 & 209 & 170 & 214 & 127 \\
\hline & & 267 & 171 & 214 & 140 & & & 277 & 172 & 216 & 140 \\
\hline & 2 & 299 & 167 & 218 & 127 & & 2 & 209 & 172 & 216 & 127 \\
\hline & & 299 & 171 & 222 & 140 & & & 277 & 174 & 216 & 140 \\
\hline & 3 & 267 & 160 & 214 & 127 & & 3 & 209 & 162 & 212 & 126 \\
\hline & & 267 & 170 & 222 & 140 & & & 283 & 172 & 216 & 140 \\
\hline & 4 & 267 & 170 & 214 & 140 & & 4 & 209 & 172 & 214 & 127 \\
\hline & & 283 & 176 & 216 & 140 & & & 283 & 174 & 216 & 140 \\
\hline \multirow[t]{8}{*}{ D } & 1 & 267 & 160 & 212 & 127 & I & 1 & 251 & 158 & 214 & 127 \\
\hline & & 343 & 160 & 214 & 140 & & & 287 & 163 & 218 & 140 \\
\hline & 2 & 209 & 160 & 214 & 127 & & 2 & 259 & 170 & 214 & 127 \\
\hline & & 271 & 168 & 224 & 140 & & & 283 & 176 & 216 & 140 \\
\hline & 3 & 209 & 162 & 214 & 140 & & 3 & 277 & 158 & 214 & 127 \\
\hline & & 343 & 172 & 222 & 140 & & & 283 & 176 & 216 & 140 \\
\hline & 4 & 209 & 162 & 214 & 127 & & 4 & 251 & 170 & 214 & 127 \\
\hline & & 271 & 162 & 216 & 140 & & & 259 & 172 & 218 & 140 \\
\hline \multirow[t]{8}{*}{ E } & 1 & 299 & 168 & 214 & 127 & & & & & & \\
\hline & & 313 & 174 & 216 & 127 & & & & & & \\
\hline & 2 & 251 & 168 & 216 & 126 & & & & & & \\
\hline & & 313 & 172 & 218 & 140 & & & & & & \\
\hline & 3 & 239 & 158 & 214 & 127 & & & & & & \\
\hline & & 299 & 162 & 216 & 140 & & & & & & \\
\hline & 4 & 243 & 158 & 214 & 126 & & & & & & \\
\hline & & 251 & 160 & 216 & 140 & & & & & & \\
\hline
\end{tabular}


Table II. Number of queen alleles per locus for each tested sister group. Sister group B (bold) shows more than $n+2$ ( $n=$ number of tested queens per group $=4$ ) alleles at two loci (A76 and $\mathrm{A} 107$ ).

\begin{tabular}{lllll}
\hline $\begin{array}{l}\text { Sister } \\
\text { group }\end{array}$ & $\begin{array}{l}\text { Locus } \\
\text { A76 }\end{array}$ & A 107 & B124 & A43 \\
\hline A & 5 & 6 & 2 & 2 \\
B & 7 & 8 & 2 & 3 \\
C & 4 & 5 & 4 & 2 \\
D & 4 & 4 & 5 & 2 \\
E & 5 & 6 & 3 & 3 \\
F & 6 & 6 & 4 & 2 \\
G & 5 & 6 & 3 & 2 \\
H & 3 & 4 & 3 & 3 \\
I & 5 & 5 & 3 & 2 \\
\hline
\end{tabular}

tions must have simultaneously occurred at two loci. This seems very unlikely in light of the low mutation rates $\left(<6.73 \times 10^{-4}\right)$ found for the four DNA microsatellite loci used in this study [6]. For our sample, null alleles can be excluded as another potential error source because not more than two homozygous worker genotypes per colony were detected at each locus. The probability of detecting unrelated queens strongly depends upon the allele frequencies of the breeding population. The non-detection error [2] is large if the maternal queen genotype is comprised of very common alleles. In our test population unrelated queens cannot be detected with $E$ ranging from $<0.001$ up to 0.005 , depending on the genotype of the mother queen of each sister queen group. This shows the high reliability of our approach.

The large sample size in the current study is associated with undesirable high costs which seem to render this method less suitable for the routine control of commercial breeding lines. A different sampling regime, however, can overcome these problems. One possibility is to sacrifice the queens after the testing period to determine their genotype directly. Alternatively, the queens' genotypes can also be determined by analysing
Table III. Allele frequencies for the tested honeybee population (size in base pairs). Only identified sexual reproductives (queens and drones) are considered.

\begin{tabular}{|c|c|c|c|}
\hline $\begin{array}{l}\text { Locus } \\
\text { A76 } \\
\text { Allele }\end{array}$ & $n=743$ & $\begin{array}{l}\text { Locus } \\
\text { A } 107 \\
\text { Allcle }\end{array}$ & $n=753$ \\
\hline 209 & 0.016 & 141 & 0.007 \\
\hline 231 & 0.04 & 158 & 0.085 \\
\hline 233 & 0.013 & 159 & 0.025 \\
\hline 239 & 0.015 & 160 & 0.114 \\
\hline 243 & 0.067 & 162 & 0.066 \\
\hline 249 & 0.018 & 163 & 0.033 \\
\hline 251 & 0.073 & 164 & 0.056 \\
\hline 255 & 0.021 & 165 & 0.02 \\
\hline 259 & 0.05 & 166 & 0.066 \\
\hline 261 & 0.044 & 167 & 0.039 \\
\hline 265 & 0.077 & 168 & 0.076 \\
\hline 267 & 0.051 & 169 & 0.009 \\
\hline 271 & 0.081 & 170 & 0.068 \\
\hline 277 & 0.028 & 171 & 0.045 \\
\hline 279 & 0.011 & 172 & 0.064 \\
\hline 281 & 0.011 & 173 & 0.015 \\
\hline 283 & 0.047 & 174 & 0.021 \\
\hline 287 & 0.047 & 175 & 0.042 \\
\hline 289 & 0.003 & 176 & 0.076 \\
\hline 291 & 0.015 & 177 & 0.053 \\
\hline 295 & 0.022 & 181 & 0.012 \\
\hline 299 & 0.059 & 183 & 0.007 \\
\hline 305 & 0.031 & 189 & 0.003 \\
\hline 311 & 0.02 & & \\
\hline 313 & 0.073 & & \\
\hline 325 & 0.007 & & \\
\hline 331 & 0.004 & & \\
\hline 343 & 0.037 & & \\
\hline 353 & 0.026 & & \\
\hline
\end{tabular}

\begin{tabular}{|c|c|c|c|}
\hline $\begin{array}{l}\text { Locus } \\
\text { B } 124 \\
\text { Allele }\end{array}$ & $n=739$ & $\begin{array}{l}\text { Locus } \\
\text { A43 } \\
\text { Allele }\end{array}$ & $n=715$ \\
\hline 212 & 0.022 & 124 & 0.001 \\
\hline 214 & 0.507 & 126 & 0.098 \\
\hline 216 & 0.242 & 127 & 0.386 \\
\hline 218 & 0.1 & 139 & 0.015 \\
\hline 220 & 0.056 & 140 & 0.443 \\
\hline 222 & 0.031 & 141 & 0.007 \\
\hline 224 & 0.009 & 142 & 0.01 \\
\hline 228 & 0.008 & 146 & 0.039 \\
\hline 230 & 0.016 & & \\
\hline 232 & 0.001 & & \\
\hline 234 & 0.007 & & \\
\hline
\end{tabular}


Table IV. Random probability of sharing putative maternal alleles by unrelated queens for each sister group and each locus $\left(e_{i}=\right.$ non-detection error for each locus, $E=$ overall non-detection error using all four microsatellites).

\begin{tabular}{|c|c|c|c|c|c|}
\hline \multirow{2}{*}{$\begin{array}{l}\text { Sister } \\
\text { group }\end{array}$} & \multicolumn{4}{|c|}{$e_{i}$} & \multirow[t]{2}{*}{$E$} \\
\hline & A76 & A 107 & B 124 & $\mathrm{~A} 43$ & \\
\hline A & 0.120 & 0.096 & 0.507 & 0.541 & 0.003 \\
\hline C & 0.110 & 0.113 & 0.538 & 0.541 & 0.004 \\
\hline D & 0.118 & 0.180 & 0.507 & 0.443 & 0.005 \\
\hline E & 0.132 & 0.161 & 0.242 & 0.541 & 0.003 \\
\hline $\mathrm{F}$ & 0.117 & 0.096 & 0.607 & 0.443 & 0.003 \\
\hline G & 0.073 & 0.199 & 0.507 & 0.386 & 0.003 \\
\hline $\mathrm{H}$ & 0.016 & 0.085 & 0.242 & 0.443 & $<0.001$ \\
\hline I & 0.120 & 0.153 & 0.507 & 0.541 & 0.005 \\
\hline
\end{tabular}

their drone offspring. Adult drones are not suitable for such an analysis as a result of the high amount of drifting drones between colonies (up to $80 \%$ ) [5] and, therefore, brood samples should be taken. Since eggs are difficult to collect from the cells and young larvae may require additional purifying steps during DNA processing (unpublished data), we suggest using a sample of drone pupae. The genotype of the queen can be reliably determined by genotyping ten drone pupae to determine potential heterozygosity at the marker locus with sufficient precision. Because worker-produced drones are eliminated through policing [9, 10] the genotype of the queen is determined accurately without sacrificing the queen. In the light of ongoing cost reductions and further automation of DNA technology, the genotyping of queens may establish itself as a routine screening of honeybee breeding lines. Already the cost of labour intensive performance testing of honeybee colonies over 1 or 2 years far exceeds that of the costs involved in our study. Therefore, we strongly recommend that the sister groups delivered to the testing apiaries should be examined to ensure that the testing reflects the actual genetic values of breeding lines rather than random effects.

\section{ACKNOWLEDGEMENTS}

We thank A. Kühl for technical assistance. We are grateful to H.R. Hepburn for useful comments on an earlier version of the manuscript. Financial support was granted by the DFG to RFAM and by a Rhodes University fellowship to PN.

\section{Résumé - Utilisation de microsatellites} d'ADN pour analyser la maternité chez les abeilles (Apis mellifera L.). Le test des performances et l'élevage sélectif des abeilles repose sur la comparaison de groupes de colonies ayant des reines sœurs, mais la présence dans les ruchers expérimentaux de reines non apparentées peut réduire à néant la valeur de l'expérience, qui est coûteuse en travail et en argent. Il semble donc utile de vérifier la lignée d'élevage des reines avant d'entamer le protocole de test. Au rucher de Schwarzenau on a effectué des analyses de maternité sur 36 colonies réparties en neuf groupes afin de déceler la présence de reines non sœurs. Des ouvrières $(n=40)$ ont été prélevées individuellement dans ces colonies, qui ont subi les tests de performance et dont on a déterminé le génotype à l'aide de quatre microsatellites d'ADN. Le génotype des reines a été déterminé à partir de celui des ouvrières (tableau I). L'uniformité des groupes testés a été évaluée par le nombre d'allèles par locus et le nombre de génotypes de reines homozygotes (tableaux $I$ et $I I$ ). Un groupe de $n$ individus renferme clairement des reines non sœurs s'il présente i) plus de deux génotypes homozygotes, ii) plus de $n$ allèles par locus, en ayant deux génotypes homozygotes, iii) plus de $n+1$ allèles par locus, en ayant un génotype homozygote, iv) plus de $n+2$ allèles par locus sans avoir de génotype homozygote. Pourtant des groupes peuvent être composés de génotypes de reines avec moins de $n, n+1$ ou $n+2$ allèles et renfermer néanmoins des reines non sœurs ; aussi a-t-on estimé les génotypes putatifs des reines mères et vérifié le génotype de toutes les reines testées. Toutes les reines sœurs doivent partager un allèle (si la mère 
est homozygote) ou l'un des deux allèles (si la mère est hétérozygote) à chaque locus. L'un des groupes (lignée B, tableau $I$ ) a présenté plus de six allèles à deux locus (A76 et A107). La probabilité de ne pas découvrir des reines non sœurs a été évaluée par les fréquences alléliques des reines et des mâles de la population d'abeilles testée (tableau III). Elle était comprise entre 0,001 et 0,005 selon le génotype de la reine mère (tableau IV, figure 1 ). Ceci montre que les microsatellites d'ADN sont capables de découvrir avec une grande probabilité des reines non sœurs. Tester les caractères des colonies implique des dépenses élevées et un gros travail. En conséquence nous recommandons d'intégrer en routine les analyses de maternité dans les tests de performances des colonies. (C) Inra/DIB/AGIB/ Elsevier, Paris

\section{Apis mellifera / microsatellite ADN / test de performances / élevage de reines / test de maternité / reine sour}

\section{Zusammenfassung - Mutterschaftsana- lysen bei Honigbienen mit Hilfe von DNA Mikrosatelliten (Apis mellifera L.). In der} Leistungsprüfung von Bienenvölkern werden Geschwistergruppen getestet. Die Anlieferung unverwandter Königinnen an die Prüfhöfe kann die Aussagekraft der arbeitsund kostenintensiven Prüfung völlig zunichte machen. Es erscheint daher hilfreich, vor Beginn der Testperiode die Prüfköniginnen auf ihre Zuchtlinie zu überprüfen. Am Prüfhof Schwarzenau (Bayern) wurden Mutterschaftsanalysen bei neun Gruppen von Geschwisterköniginnen durchgeführt, um unverwandte Königinnen zu entdecken. Individuelle Arbeiterinnen $(n=40)$ wurden aus 36 weiselrichtigen Völkern entnommen, die der Leistungsprüfung unterzogen wurden, und mit Hilfe von vier DNA Mikrosatelliten genotypisiert. Die Genotypen der Königinnen wurden mit Hilfe der Arbeiterinnen ermittelt (Tabelle I). Die Integrität der Prüfgruppen wurde mit Hilfe der
Anzahl an Mikrosatelliten-Allelen je Locus und der Anzahl an homozygoten Königinnengenotypen bestimmt (Tabelle $I, I I$ ). Unverwandte Königinnen sind definitiv in einer Gruppe aus $n$ Geschwisterköniginnen enthalten wenn: 1. Eine Gruppe mehr als zwei verschiedene homozygote Genotypen aufweist. 2. Eine Gruppe mit zwei verschiedenen homozygoten Genotypen mehr als $n$ Allele je Locus aufweist. 3. Eine Gruppe mit einem homozygoten Genotyp mehr als $n+1$ Allele je Locus aufweist. 4. Eine Gruppe ohne homozygoten Genotyp mehr als $n+2$ Allele je Locus aufweist. Da jedoch auch Gruppen mit weniger Allelen unverwandte Königinnen enthalten können, wurden die putativen Genotypen der Mutterköniginnen bestimmt und die Genotypen aller getesteten Königinnen überprüft. Alle Geschwister müssen ein Allel (bei Homozygotie der Mutter) oder ein von zwei Allelen (bei Heterozygotie der Mutter) teilen. Eine der Prüfgruppen (Zuchtlinie B, Tabelle 2) wies mehr als 6 Allele an zwei Loci auf (A76 und A 107). Die Wahrscheinlichkeit, unverwandte Königinnen nicht zu entdecken, wurde mit Hilfe der Allelfrequenzen von Königinnen und Drohnen der getesteten Honigbienenpopulation (Tabelle 3) abgeschätzt (s. Formeln 1 und 2) und reichte von $E=<0,001$ bis zu $E=0,005$, abhängig vom jeweiligen Genotyp der Mutterkönigin (Tabelle 4, Abbildung 1). Dies zeigt, da $\beta$ DNA Mikrosatelliten in der Lage sind, unverwandte Königinnen mit hoher Wahrscheinlichkeit zu entdecken. In Anbetracht der hohen Kosten und arbeitsintensiven Überprüfung der Leistungsmerkmale empfehlen wir daher Mutterschaftsanalysen routinemäßig in die Leistungsprüfung zu integrieren. (C) Inra/DIB/AGIB/Elsevier, Paris

\section{Apis mellifera / DNA Mikrosatelliten / Honigbiene / Königinnenzucht / Mutter- schaftsanalyse / Geschwisterkönigin}




\section{REFERENCES}

[1] Bayerische Landesanstalt für Bienenzucht, Leistungsprüfung 1993-1995, Prüfhof Schwarzenau, Abschlußbericht, Bayerische Landesanstalt für Bienenzucht, Erlangen, 1995.

[2] Boomsma J.J., Ratnieks F.L.W., Paternity in eusocial Hymenoptera, Phil. Trans. R. Soc. B 331 (1996) 947-975.

[3] Estoup A., Solignac M., Harry M., Cornet J.M., Characterisation of (GT)n and (CT)n microsatellites in two insect species: Apis mellifera and Bombus terrestris, Nucleic Acids Res. 21 (1993) 1427-1431.

[4] Estoup A., Solignac M., Cornuet J.M., Precise assessment of the number of patrilines and genetic relatedness in honeybee colonies, Proc. R. Soc. Lond. B 258 (1994) 1-7.

[5] Kühl A., Neumann P., Analysis of the drifting of drones at an apiary using single locus DNA-fingerprinting, Apidologie 27 (1996) 301-302.
[6] Neumann P., Fondrk K., Page R., Moritz R.F.A., Testing the reliability of DNA-microsatellites in instrumental inseminated queen-honeybees (Apis mellifera L.), in: Crailsheim K., Stabentheiner A. (Eds.), Soziale Insekten, IUSSITagung Graz 1997, Graz, Austria, 1997. p. 66 .

[7] Neumann P., Moritz R.F.A., van Praagh J., Queen mating-frequency in different types of honeybee mating apiaries, J. Apic. Res. 38 (1999) 11-18.

[8] Neumann P., van Praagh J.P., Moritz R.F.A., Dustmann J., Testing reliability of a potential honeybee island mating apiary using DNA microsatellites, Apidologie 30 (1999) 257-276.

[9] Ratnieks F.L.W., Visscher P.K., Worker policing in the honey bee, Nature 342 (1989) 796-797.

[10] Visscher P.K., A quantitative study of worker reproduction in queenright honey bee colonies, Behav. Ecol. Sociobiol. 25 (1989) 247-254. 